\title{
Study on regioselective synthesis of bioactive bis-spiropyrazolines using molecular orbital calculations
}

\author{
Thoraya Abd El-Reheem Farghaly*, Ikhlass Mohamed Abbas, \\ Walid Mohamed Ibrahim Hassan and Mai Samir Lotfy \\ Department of Chemistry, Faculty of Science, Cairo University, Giza, 12613, Egypt \\ ${ }^{*}$ Corresponding author at: Department of Chemistry, Faculty of Science, Cairo University, Giza, 12613, Egypt. \\ Tel.: +2.02.35676608. Fax: +2.02.35676501. E-mail address: thoraya-f@hotmail.com (T.A.E. Farghaly).
}

\section{ARTICLE INFORMATION}

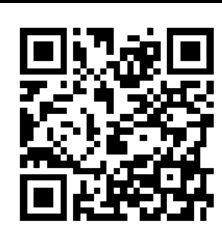

DOI: 10.5155 /eurjchem.5.4.577-583.1039

Received: 02 March 2014

Received in revised form: 29 May 2014

Accepted: 13 June 2014

Online: 31 December 2014

\section{KEYWORDS}

\section{Nitrilimine}

Regioselectivity

Bis-spiropyrazole

Antimicrobial activity

Molecular orbital calculations

1,3-Dipolar cycloaddition reaction

\section{Introduction}

Spiro and bis-spiro-heterocyclic compounds represent an important class of substances characterized by highly pronounced biological properties [1-4]. The most developed phenomenon for the synthesis of these compounds depends mainly on cycloaddition reaction to exocyclic double bonds [59]. 1,3-Dipolar cycloaddition reactions are considered the most successful process for the construction of five-membered ring containing spiro and bis-spiro-compounds due to high regioand stereo-selective properties of these reactions $[10,11]$. From this reaction, pyrazolines derivatives are one of the synthesized compounds. These compounds have been found to exhibit considerable biological activities such as antibacterial [12-16], antifungal [15-17], antiviral [15], anti-inflammatory [18-23], analgesic [19], and antidepressant ones [24].

In the present work and in continuation to our previous work concerning with reactions of nitrilimines [25-29], we investigate the synthesis of spiropyrazoline-containing compounds through 1,3-dipolar cycloaddition reaction of nitrilimines to various bis-exocyclic olefinic linkage containing compounds. This investigation will allow not only to study the regiochemistry of 1,3-dipolar cycloaddition reaction at neighboring olefinic linkages, but also to prepare novel bis-spiro pyrazoline containing compounds with an element of symmetry which is a characteristic property of many biologically active natural and synthetic compounds [30]. Also, we interested to study the mechanism of this reaction since in the absence of quantum chemical calculations for this mechanism, the product can be verified by spectroscopic methods, but give no reason for the stereoselectivity of the reaction. In this study we have performed quantum chemical calculations to investigate why one of these mechanisms are favored over the other.

\section{Experimental}

\subsection{Chemistry}

\subsubsection{Instrumentation}

Melting points were measured on Electrothermal IA 9000 series digital melting point apparatus. The IR spectra were recorded in potassium bromide discs on a Pye Unicam SP 3300 and Shimadzu FTIR 8101 PC infrared spectrophotometers. The NMR spectra were recorded on a Varian Mercury VX-300 NMR spectrometer operating at $300 \mathrm{MHz}\left({ }^{1} \mathrm{H} \mathrm{NMR}\right)$ or $100 \mathrm{MHz}\left({ }^{13} \mathrm{C}\right.$ NMR) and run in deuterated dimethylsulphoxide (DMSO- $d_{6}$ ). 


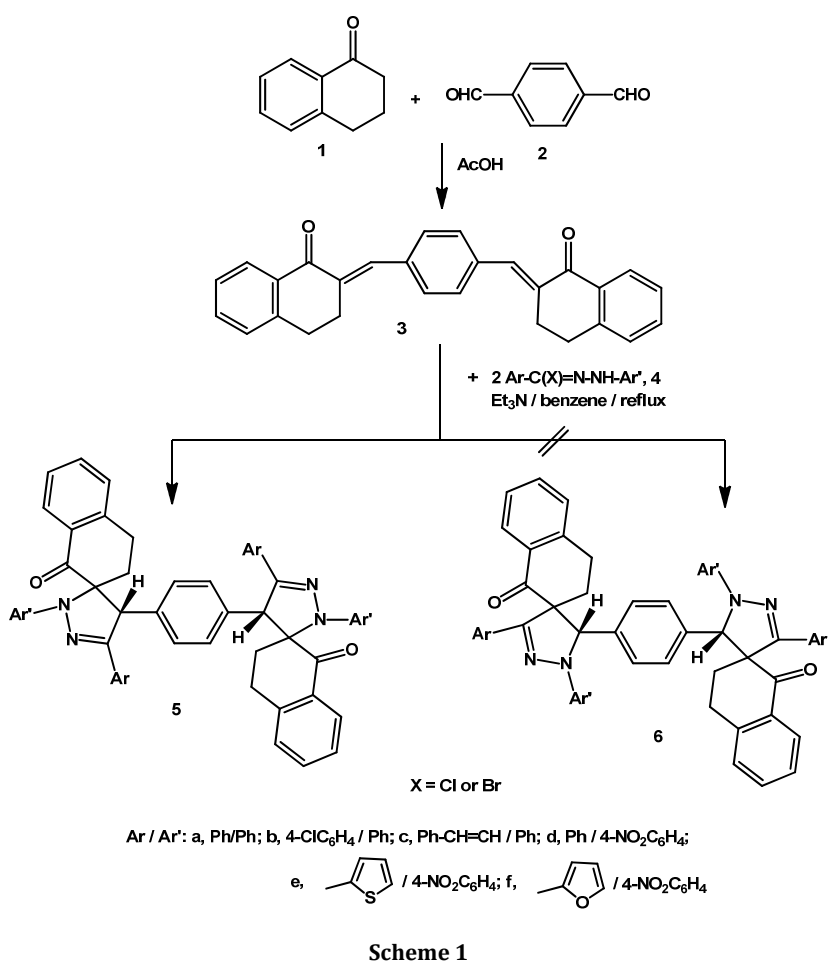

Chemical shifts were related to that of the solvent. Mass spectra were recorded on a Shimadzu GCMS-QP1000 EX mass spectro-meter at $70 \mathrm{eV}$. Elemental analyses were measured by using a German made Elementar Vario LIII CHNS analyzer. The starting compounds $\mathbf{3}, \mathbf{8}$ and hydrazonoyl chlorides were prepared as previously described in the literature [31-34].

\subsubsection{Reaction of compound 3 and 4}

A mixture of compound $\mathbf{3}$ or $8(2.5 \mathrm{mmol})$ and the appropriate hydrazonoyl halides 4 a-e $(5 \mathrm{mmol})$ in dry benzene $(30 \mathrm{~mL})$ containing triethylamine $(7.5 \mathrm{mmol})$ was heated under reflux for the appropriate time. The reaction mixture was filtered while hot to remove the triethylamine hydrochloride, then concentrated to $10 \mathrm{~mL}$ and cooled overnight. The separated solid was collected and crystallized from ethanol:dioxane $(20: 80, v: v)$ and affording the corresponding products $\mathbf{5 a - f ,} \mathbf{9 a - c , f , e ~ o r ~ 1 0 a , d ~ ( S c h e m e ~} 1$ and 2).

4'-(4-(5'-(Phenyl)-1-oxo-2'-phenyl-2',3,4,4'-tetrahydro-1Hspiro[naphthalene-2,3'-pyrazol]-4'-yl)phenyl)-5'-(phenyl)-2'phenyl-2',3,4,4'-tetrahydro-1H-spiro[naphthalene-2,3'pyrazol]-1-one (5a): Color: Yellow. Yield: 70\%. M.p: $>300{ }^{\circ} \mathrm{C}$. FT-IR (KBr, $\left.v, \mathrm{~cm}^{-1}\right): 1676(\mathrm{CO}) .{ }^{1} \mathrm{H}$ NMR $\left(300 \mathrm{MHz}\right.$, DMSO- $d_{6}, \delta$, ppm): $1.94\left(\mathrm{t}, J=7 \mathrm{~Hz}, 4 \mathrm{H}, 2 \mathrm{CH}_{2}\right), 2.87\left(\mathrm{t}, J=7 \mathrm{~Hz}, 4 \mathrm{H}, 2 \mathrm{CH}_{2}\right)$, 5.17 (s, 2H, 2CH), 6.83-8.02 (m, 28H, Ar-H), 8.31 (s, 4H, ArH). MS (EI, $m / z(\%)): 779\left(\mathrm{M}^{+}+1,23\right), 778\left(\mathrm{M}^{+}, 38\right), 777(27), 673$ (20), 672 (30), 659 (31), 430 (21), 389 (29), 277 (17), 207 (36), 206 (42), 204 (22), 165 (22), 130 (92), 128 (23), 115 (30), 105 (30), 103 (43), 91 (100), 84 (14), 77 (77). Anal. calcd. for: $\mathrm{C}_{54} \mathrm{H}_{42} \mathrm{~N}_{4} \mathrm{O}_{2}: \mathrm{C}, 83.26 ; \mathrm{H}, 5.43 ; \mathrm{N}, 7.19$. Found: C, 83.35; H, 5.64; $\mathrm{N}, 7.01 \%$.

4'-(4-(5'-(4-Chloro phenyl)-1-oxo-2'-phenyl-2',3,4,4'-tetra hydro-1H-spiro[naphthalene-2,3'-pyrazol]-4'-yl)phenyl)-5'-(4chloro phenyl)-2'-phenyl-2',3,4,4'-tetrahydro-1H-spiro[naphtha lene-2,3'-pyrazol]-1-one (5b): Color: Dark orange solid. Yield: $63 \%$. M.p: $190{ }^{\circ} \mathrm{C}$. FT-IR (KBr, v, cm$\left.{ }^{-1}\right): 1684$ (CO). ${ }^{1} \mathrm{H}$ NMR (300 MHz, DMSO- $\left.d_{6}, \delta, p p m\right): 1.06\left(\mathrm{t}, J=7 \mathrm{~Hz}, 4 \mathrm{H}, 2 \mathrm{CH}_{2}\right), 2.89(\mathrm{t}$, $\left.J=7 \mathrm{~Hz}, 4 \mathrm{H}, 2 \mathrm{CH}_{2}\right), 5.20(\mathrm{~s}, 2 \mathrm{H}, 2 \mathrm{CH}), 7.07-8.01(\mathrm{~m}, 30 \mathrm{H}, \mathrm{Ar}-\mathrm{H})$. MS (EI, $m / z(\%)$ ): $848\left(\mathrm{M}^{+}+1,6\right), 847\left(\mathrm{M}^{+}, 13\right), 817$ (57), 207
(45), 130 (81), 128 (38), 115 (43), 105 (32), 103 (40), 93 (47), 91 (100), 89 (53), 77 (77), 73 (36), 63 (45), 60 (60), 54 (38). Anal. calcd. for: $\mathrm{C}_{54} \mathrm{H}_{40} \mathrm{Cl}_{2} \mathrm{~N}_{4} \mathrm{O}_{2}: \mathrm{C}, 76.50 ; \mathrm{H}, 4.76 ; \mathrm{N}, 6.61$. Found: C, 76.38; H, 4.49; N, 6.48\%.

4'-(4-(2'-(Phenyl)-1-oxo-5'-((E)-styryl)-2',3,4,4'-tetrahydro$1 H$-spiro[naphthalene-2,3'-pyrazol]-4'-yl)phenyl)-2'-(phenyl)-5'((E)-styryl)-2',3,4,4'-tetrahydro-1H-spiro[naphthalene-2,3'pyrazol]-1-one (5c): Color: Dark orange solid. Yield: 75\%. M.p: $150{ }^{\circ} \mathrm{C}$. FT-IR (KBr, v, cm ${ }^{-1}$ ): 1682 (CO). ${ }^{1} \mathrm{H}$ NMR $(300 \mathrm{MHz}$, DMSO- $\left.d_{6}, \delta, \mathrm{ppm}\right): 2.00-3.15\left(\mathrm{~m}, 8 \mathrm{H}, 4 \mathrm{CH}_{2}\right), 5.04(\mathrm{~s}, 2 \mathrm{H}, 2 \mathrm{CH})$, $6.40(\mathrm{~d}, J=12 \mathrm{~Hz}, 2 \mathrm{H}, 2 \mathrm{CH}=), 6.50(\mathrm{~d}, J=12 \mathrm{~Hz}, 2 \mathrm{H}, 2 \mathrm{CH}=), 6.99$ $8.03(\mathrm{~m}, 32 \mathrm{H}, \mathrm{Ar}-\mathrm{H})$. MS (EI, $m / z(\%)): 831\left(\mathrm{M}^{+}+1,5\right), 830\left(\mathrm{M}^{+}\right.$, 12), 610 (37), 609 (63), 490 (40), 304 (26), 206 (40), 129 (44), 127 (42), 114 (30), 104 (40), 91 (100), 89 (37), 77 (86), 64 (30), 58 (30). Anal. calcd. for: $\mathrm{C}_{58} \mathrm{H}_{46} \mathrm{~N}_{4} \mathrm{O}_{2}: \mathrm{C}, 83.83 ; \mathrm{H}, 5.58 ; \mathrm{N}$, 6.74. Found: C, 83.68; H, 5.37; N, 6.69\%.

5'-(Phenyl)-2'-(4-nitro phenyl)-4'-(4-(2'-(4-nitro phenyl)-1oxo-5'-(phenyl)-2',3,4,4'-tetrahydro-1H-spiro[naphthalene-2,3'pyrazol]-4'-yl)phenyl)-2',3,4,4'-tetrahydro-1H-spiro[naphthale ne-2,3'-pyrazol]-1-one (5d): Color: Brown solid. Yield: $68 \%$. M.p: $130{ }^{\circ} \mathrm{C}$. FT-IR (KBr, v, cm-1): 1677 (CO). ${ }^{1} \mathrm{H}$ NMR $(300 \mathrm{MHz}$ DMSO- $\left.d_{6}, \delta, \mathrm{ppm}\right): 2.50-3.29\left(\mathrm{~m}, 8 \mathrm{H}, 4 \mathrm{CH}_{2}\right), 5.52(\mathrm{~s}, 2 \mathrm{H}, 2 \mathrm{CH})$, 7.28-8.14 (m, 30H, Ar-H). MS (EI, $m / z(\%)): 868\left(\mathrm{M}^{+}, 14\right), 867$ (27), 433 (32), 205 (32), 162 (32), 115 (41), 110 (41), 107 (41), 105 (46), 102 (46), 92 (32), 89 (36), 83 (37), 78 (37), 77 (100) 73 (41), 71 (50), 69 (59), 67 (46), 63 (73), 60 (50), 57 (68), 55 (55). Anal. calcd. for: $\mathrm{C}_{54} \mathrm{H}_{40} \mathrm{~N}_{6} \mathrm{O}_{6}: \mathrm{C}, 74.64 ; \mathrm{H}, 4.64 ; \mathrm{N}, 9.67$. Found: C, 74.48; H, 4.50; N, 9.43\%.

2'-(4-Nitrophenyl)-4'-(4-(1-oxo-5'-(thiophen-2-yl)-2'-(4-nitro phenyl)-2',3,4,4'-tetrahydro-1H-spiro[naphthalene-2,3'-pyrazol]4'-yl)phenyl)-5'-(thiophen-2-yl)-2',3,4,4'-tetrahydro-1H-spiro [naphthalene-2,3'-pyrazol]-1-one (5e): Color: Dark orange solid. Yield: 69 \%. M.p: 220-222 ${ }^{\circ} \mathrm{C}$. FT-IR (KBr, v, cm-1): 1677 (CO). ${ }^{1} \mathrm{H}$ NMR $\left(300 \mathrm{MHz}\right.$, DMSO- $\left.d_{6}, \delta, \mathrm{ppm}\right): 2.20-3.05\left(\mathrm{~m}, 8 \mathrm{H}, 4 \mathrm{CH}_{2}\right)$, 5.41 (s, 2H, 2CH), 6.99-8.14 (m, 26H, Ar-H). MS (EI, $m / z(\%)$ ): $881\left(\mathrm{M}^{+}+1,6\right), 880\left(\mathrm{M}^{+}, 30\right), 848(10), 847(13), 115(32), 112$ (19), 109 (55), 92 (32), 91 (45), 84 (19), 82 (32), 72 (48), 57 (100). Anal. calcd. for: $\mathrm{C}_{50} \mathrm{H}_{36} \mathrm{~N}_{6} \mathrm{O}_{6} \mathrm{~S}_{2}$ : C, 68.17; $\mathrm{H}, 4.12 ; \mathrm{N}, 9.54$ Found: C, 68.02; H, 4.0; N, 9.35\%. 


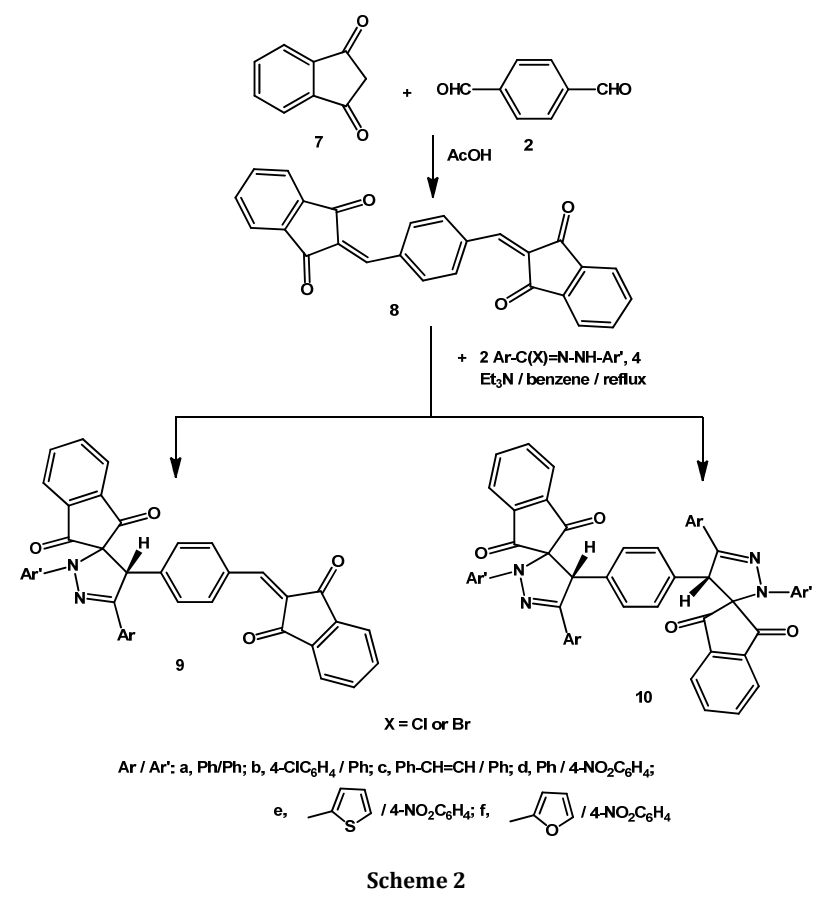

5'-(Furan-2-yl)-2'-(4-nitrophenyl)-4'-(4-(2'-(4-nitrophenyl)1-oxo-5'-(furan-2-yl)-2',3,4,4'-tetrahydro-1H-spiro[naphthalene2,3'-pyrazol]-4'-yl)phenyl)-2',3,4,4'-tetrahydro-1H-spiro[naphtha lene-2,3'-pyrazol]-1-one (5f): Color: Orange solid. Yield: $81 \%$. M.p: $212{ }^{\circ} \mathrm{C}$. FT-IR (KBr, v, cm-1 $): 1660$ (CO). ${ }^{1} \mathrm{H}$ NMR $(300 \mathrm{MHz}$, DMSO- $\left.d_{6}, \delta, \mathrm{ppm}\right): 2.00-3.20\left(\mathrm{~m}, 8 \mathrm{H}, 4 \mathrm{CH}_{2}\right), 5.26(\mathrm{~s}, 2 \mathrm{H}, 2 \mathrm{CH})$, $6.65(\mathrm{~d}, J=8 \mathrm{~Hz}, 4 \mathrm{H}, \mathrm{Ar}-\mathrm{H}), 6.88$ (d, $J=8 \mathrm{~Hz}, 4 \mathrm{H}, \mathrm{Ar}-\mathrm{H}), 7.64(\mathrm{~s}$, $4 \mathrm{H}, \mathrm{Ar}-\mathrm{H}), 7.42-7.46$ and 7.82-8.24 (m, $14 \mathrm{H}, \mathrm{Ar}-\mathrm{H})$. MS (EI, $m / z$ (\%)): $847\left(\mathrm{M}^{+}-1,5\right), 804$ (5), 486 (13), 128 (10), 97 (27), 95 (18), 77 (10), 76 (19). Anal. calcd. for: $\mathrm{C}_{50} \mathrm{H}_{36} \mathrm{~N}_{6} \mathrm{O}_{8}$ : C, 70.75; $\mathrm{H}$, 4.27; N, 9.90. Found: C, 70.58; H, 4.45; N, 9.81\%.

4'-(4-((1,3-Dioxo-1H-inden-2(3H)-ylidene)methyl)phenyl)2',5'-diphenyl-2',4'-dihydrospiro[indene-2,3'-pyrazole]-1,3dione (9a): Color: Orange solid. Yield: $71 \%$. M.p: > $300^{\circ}$ C. FTIR (KBr, $\left.v, \mathrm{~cm}^{-1}\right)$ : 1746, 1707 (CO). ${ }^{1} \mathrm{H}$ NMR (300 MHz, DMSO- $d_{6}$, $\delta, \mathrm{ppm}): 5.34(\mathrm{~s}, 1 \mathrm{H}, \mathrm{CH}), 6.76-7.58(\mathrm{~m}, 22 \mathrm{H}, \mathrm{Ar}-\mathrm{H}), 9.90(\mathrm{~s}, 1 \mathrm{H}$, $=\mathrm{CH}) .{ }^{13} \mathrm{C}$ NMR (100 MHz, $\left.\mathrm{CDCl}_{3}, \delta, \mathrm{ppm}\right): 61.49,79.70,113.77$, $123.90,124.24,125.26,127.04,129.27,129.77,129.91,130.24$, $130.48,130.69,131.25,135.16,136.29,137.50,138.33,139.21$, 140.72, 143.02, 147.67, 193.21, 194.14, 196.34. MS (EI, $\mathrm{m} / \mathrm{z}$ (\%)): $586\left(\mathrm{M}^{+}+1,4\right), 585\left(\mathrm{M}^{+}, 4\right), 456(20), 411(42), 104$ (100), 88 (23), 77 (85), 75 (25), 57 (30), 55 (32), 51 (39). Anal. calcd. for: $\mathrm{C}_{39} \mathrm{H}_{24} \mathrm{~N}_{2} \mathrm{O}_{4}$ : C, $80.12 ; \mathrm{H}, 4.14 ; \mathrm{N}, 4.79$. Found: $\mathrm{C}, 80.05 ; \mathrm{H}$, $4.25 ; \mathrm{N}, 4.65 \%$.

2'-(4-Chlorophenyl)-4'-(4-((1,3-dioxo-1H-inden-2(3H)-ylide ne)methyl)phenyl)-5'-phenyl-2',4'-dihydrospiro[indene2,3'-pyrazole]-1,3-dione (9b): Color: Red solid. Yield: 65 \%. M.p: $>300{ }^{\circ} \mathrm{C}$. FT-IR (KBr, v, cm $\left.{ }^{-1}\right): 1739,1707$ (CO). ${ }^{1} \mathrm{H}$ NMR $(300$ MHz, DMSO- $\left.d_{6}, \delta, \mathrm{ppm}\right): 5.41(\mathrm{~s}, 1 \mathrm{H}, \mathrm{CH}), 6.76-7.16$ and 7.73$8.19(\mathrm{~m}, 17 \mathrm{H}, \mathrm{Ar}-\mathrm{H}), 7.39$ (d, $J=8 \mathrm{~Hz}, 2 \mathrm{H}, \mathrm{Ar}-\mathrm{H}), 7.58(\mathrm{~d}, J=8 \mathrm{~Hz}$, $2 \mathrm{H}, \mathrm{Ar}-\mathrm{H}$ ), $9.90\left(\mathrm{~s}, 1 \mathrm{H},=\mathrm{CH}\right.$ ). Anal. calcd. for: $\mathrm{C}_{39} \mathrm{H}_{23} \mathrm{ClN}_{2} \mathrm{O}_{4}$ : C, 75.67; H, 3.74; N, 4.53. Found: C, 75.52; H, 3.56; N, 4.32\%.

(E)-4'-(4-((1,3-Dioxo-1H-inden-2(3H)-ylidene)methyl) phenyl)-5'-phenyl-2'-styryl-2',4'-dihydrospiro[indene-2,3'pyrazole]-1,3-dione (9c): Color: Orange solid. Yield: $62 \%$. M.p: $>300{ }^{\circ} \mathrm{C}$. FT-IR (KBr, v, cm$\left.{ }^{-1}\right): 1747,1708$ (CO). ${ }^{1} \mathrm{H}$ NMR $(300$ MHz, DMSO- $d_{6}, \delta, \mathrm{ppm}$ ): $5.28(\mathrm{~s}, 1 \mathrm{H}, \mathrm{CH}), 6.70(\mathrm{~d}, J=12 \mathrm{~Hz}, 1 \mathrm{H}$, $=\mathrm{CH}), 6.82-8.19(\mathrm{~m}, 23 \mathrm{H}, \mathrm{Ar}-\mathrm{H}$ and $=\mathrm{CH}), 9.93(\mathrm{~s}, 1 \mathrm{H},=\mathrm{CH})$. MS (EI, $m / z(\%)$ ): $610\left(\mathrm{M}^{+}, 2\right), 481$ (100), 104 (58), 77 (94), 75
(45), 60 (50), 57 (45), 51 (32). Anal. calcd. for: $\mathrm{C}_{41} \mathrm{H}_{26} \mathrm{~N}_{2} \mathrm{O}_{4}$ : C 80.64; H, 4.29; N, 4.59. Found: C, 80.41; H, 4.13; N, 4.26\%.

4'-(4-((1,3-Dioxo-1H-inden-2(3H)-ylidene)methyl)phenyl)-2'(4-nitrophenyl)-5'-(thiophen-2-yl)-2',4'-dihydrospiro[indene-2,3'pyrazole]-1,3-dione (9e): Color: Dark green solid. Yield: $60 \%$. M.p: > $300{ }^{\circ} \mathrm{C}$. FT-IR (KBr, v, cm${ }^{-1}$ ):1748, 1700 (CO). ${ }^{1} \mathrm{H}$ NMR (300 MHz, DMSO- $\left.d_{6}, \delta, \mathrm{ppm}\right): 5.34(\mathrm{~s}, 1 \mathrm{H}, \mathrm{CH}), 6.82-8.35(\mathrm{~m}$, 19H, Ar-H), $9.93(\mathrm{~s}, 1 \mathrm{H},=\mathrm{CH})$. MS (EI, $m / z(\%)): 637\left(\mathrm{M}^{+}+2\right.$, 0.01), 138 (5), 108 (3), 103 (6), 97 (11), 90 (47), 75 (49), 73 (28), 68 (26), 62 (69), 57 (100), 55 (79). Anal. calcd. for: $\mathrm{C}_{37} \mathrm{H}_{21} \mathrm{~N}_{3} \mathrm{O}_{6} \mathrm{~S}: \mathrm{C}, 69.91 ; \mathrm{H}, 3.33 ; \mathrm{N}, 6.61$. Found: $\mathrm{C}, 69.74 ; \mathrm{H}, 3.15$; $\mathrm{N}, 6.49 \%$.

4'-(4-((1,3-Dioxo-1H-inden-2(3H)-ylidene)methyl)phenyl)-5'(furan-2-yl)-2'-(4-nitrophenyl)-2', 4'-dihydrospiro[indene-2,3'pyrazole]-1,3-dione (9f): Color: Brown solid. Yield: 68 \%. M.p: > $300{ }^{\circ} \mathrm{C}$. FT-IR (KBr, v, cm$\left.{ }^{-1}\right): 1730,1702$ (CO). ${ }^{1} \mathrm{H}$ NMR $(300$ MHz, DMSO- $\left.d_{6}, \delta, \mathrm{ppm}\right): 5.08$ (s, $\left.1 \mathrm{H}, \mathrm{CH}\right), 6.54-8.23(\mathrm{~m}, 19 \mathrm{H}, \mathrm{Ar}-$ H), $9.92(\mathrm{~s}, 1 \mathrm{H},=\mathrm{CH})$. MS (EI, $m / z(\%)): 619\left(\mathrm{M}^{+}, 10\right), 604(20)$, 519 (17), 149 (30), 130 (33), 105 (80), 104 (43), 64 (100), 77 (70). Anal. calcd. for: $\mathrm{C}_{37} \mathrm{H}_{21} \mathrm{~N}_{3} \mathrm{O}_{7}$ : $\mathrm{C}, 71.73 ; \mathrm{H}, 3.42 ; \mathrm{N}, 6.78$. Found: C, 71.57; H, 3.28; N, 6.56\%.

4'-(4-(5'-(Phenyl)-1, 3-dioxo-2'-phenyl-1, 2', 3, 4'-tetrahydro spiro[indene-2,3'-pyrazol]-4'-yl)phenyl)-2',5'-diphenyl-2',4'dihydrospiro[indene-2,3'-pyrazole]-1,3-dione (10a): Color: Dark red. Yield: $72 \%$. M.p.: $>300{ }^{\circ} \mathrm{C}$. FT-IR $\left(\mathrm{KBr}, v, \mathrm{~cm}^{-1}\right): 1747,1712$ (CO). ${ }^{1} \mathrm{H}$ NMR $\left(300 \mathrm{MHz}\right.$, DMSO- $\left.d_{6}, \delta, \mathrm{ppm}\right): 5.12(\mathrm{~s}, 2 \mathrm{H}, 2 \mathrm{CH})$, 6.70-8.16 (m, 28H, Ar-H), 7.29 (s, 4H, Ar-H). ${ }^{13} \mathrm{C}$ NMR (100 MHz, $\left.\mathrm{CDCl}_{3}, \delta, \mathrm{ppm}\right): 66.88,106.07,109.74,113.40,113.60,120.59$, $126.62,126.83,126.99,129.03,129.61,129.86,130.06,138.29$, 143.69, 172.30, 196.40. MS (EI, $m / z(\%)): 779\left(\mathrm{M}^{+}+1,9\right), 778$ $\left(\mathrm{M}^{+}, 16\right), 777$ (20), 365 (26), 350 (25), 104 (73), 93 (38), 91 (33), 77 (100), 75 (26), 71 (26), 69 (25), 64 (44), 57 (42), 55 (33), 51 (64). Anal. calcd. for: $\mathrm{C}_{52} \mathrm{H}_{34} \mathrm{~N}_{4} \mathrm{O}_{4}$ : C, 80.19; $\mathrm{H}, 4.40$; $\mathrm{N}$, 7.19. Found: C, $80.03 ; \mathrm{H}, 4.35 ; \mathrm{N}, 7.08 \%$.

4'-(4-(2'-(4-Nitro phenyl)-1,3-dioxo-5'-phenyl-1,2',3,4'-tetra hydrospiro[indene-2,3'-pyrazol]-4'-yl)phenyl)-2'-(4-nitrophenyl)5'-phenyl-2',4'-dihydrospiro[indene-2,3'-pyrazole]-1,3-dione (10d): Color: Red solid. Yield: 84 \%. M.p: $>300^{\circ} \mathrm{C}$. FT-IR (KBr, $\left.v, \mathrm{~cm}^{-1}\right): 1751,1708$ (CO). ${ }^{1} \mathrm{H}$ NMR (300 MHz, DMSO- $\left.d_{6}, \delta, \mathrm{ppm}\right):$ $5.30(\mathrm{~s}, 2 \mathrm{H}, 2 \mathrm{CH}), 6.85-8.40(\mathrm{~m}, 30 \mathrm{H}, \mathrm{Ar}-\mathrm{H})$. 
Table 1. Shows the total energy, energy of HOMO, energy of LUMO in a. u. and energy gap $\Delta E$ in eV.

\begin{tabular}{|c|c|c|c|c|}
\hline Compound & Total energy & $\boldsymbol{E}_{\text {номо }}$ & $E_{\text {Lumo }}$ & $\Delta E(\mathrm{eV})$ \\
\hline 3 & -1300.410605 & -0.24633 & -0.12643 & 3.262683 \\
\hline $4 a$ & -1071.8617192 & -0.20609 & -0.05842 & 4.018352 \\
\hline $4 b$ & -1531.4833465 & -0.21065 & -0.06667 & 3.917941 \\
\hline $4 \mathrm{c}$ & -1149.2882691 & -0.20122 & -0.07103 & 3.542691 \\
\hline $4 d$ & -1276.4207453 & -0.22878 & -0.09189 & 3.72501 \\
\hline $4 \mathrm{e}$ & -1597.1834239 & -0.22455 & -0.09267 & 3.588679 \\
\hline $5 a$ & -2453.0428513 & -0.18741 & -0.07420 & 3.080637 \\
\hline $6 \mathrm{a}$ & -2453.0439845 & -0.19770 & -0.07758 & 3.26869 \\
\hline
\end{tabular}

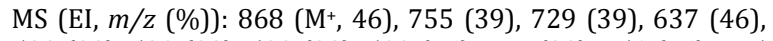
598 (39), 590 (39), 523 (39), 509 (46), 477 (39), 451 (46), 445 (46), 421 (39), 370 (54), 323 (46), 210 (46), 135 (46), 123 (31), 114 (46), 112 (31), 110 (39), 93 (39), 81 (54), 77 (69), 74 (39), 69 (46), 57 (100), 54 (54), 52 (39). Anal. calcd. for: $\mathrm{C}_{52} \mathrm{H}_{32} \mathrm{~N}_{6} \mathrm{O}_{8}$ : C, 71.88; H, 3.71; N, 9.67. Found: C, 71.68; H, 3.59; N, 9.52\%.

\subsection{Biological activity}

\subsubsection{Antimicrobial activity}

Antimicrobial activity was determined using the agar well diffusion assay method as described by Holder and Boyce [35]. The tested organisms were sub-cultured on nutrient agar medium (Oxoid Laboratories, UK) for bacteria and Sabouraud dextrose agar (Oxoid Laboratories, UK) for fungi. Penicillin G and Streptomycin were used as a positive control for bacterial strains. Amphotericin B was used as a positive control for fungi. The plates were done in triplicate. Bacterial cultures were incubated at $37^{\circ} \mathrm{C}$ for $24 \mathrm{~h}$ while the other fungal cultures were incubated at $\left(25-30^{\circ} \mathrm{C}\right)$ for 3-7 days. Antimicrobial activity was determined by measurement zone of inhibition [36].

\subsubsection{Determination of minimum inhibitory concentration (MIC)}

The minimum inhibitory concentration of the samples was estimated for each of the tested organisms in triplicates. Varying concentrations of the samples (1000-0.007 $\mu \mathrm{g} / \mathrm{mL})$, nutrient broth was added and then a loop full of the test organism previously diluted to 0.5 McFarland turbidity standard was introduced to the tubes. A tube containing broth media only was seeded with the test organisms to serve as control. Tubes containing tested organisms cultures were then incubated at $37^{\circ} \mathrm{C}$ for $24 \mathrm{~h}$ while the other fungal cultures were incubated at $\left(25-30{ }^{\circ} \mathrm{C}\right)$ for 3-7 days. The tubes were then examined for growth by observing for turbidity [37].

\subsubsection{Media used}

Sabouraud's glucose agar with antibiotic: The medium used for isolation of pathogenic yeasts has the following composition (g/L): Glucose, 20; peptone, 10; agar, 25 and distilled water, 1 $\mathrm{L}, \mathrm{pH}$ was adjusted at 5.4. The medium was autoclaved at 115 ${ }^{\circ} \mathrm{C}$ for $15 \mathrm{~min}$ then $0.5 \mathrm{~g} / \mathrm{L}$. Chloramphenicol was added to avoid bacterial growth [38].

Nutrient agar (NA): The medium was used to cultivate tested bacteria. It contains (g/L) Beef extract, 3; Peptone, 5 and distilled water $1 \mathrm{~L} \mathrm{[39].}$

\section{Results and discussion}

\subsection{Chemistry}

Reaction of terphthalaldehyde (2) with two mole equivalents of 3,4-dihydro-(2H)-naphthalen-1-one (1) in ethanolic $\mathrm{KOH}$ solution afforded directly $\left(2 E, 2^{\prime} E\right)-2,2^{\prime}-(1,4-$ phenylene bis(methanylylidene))bis(3,4-dihydronaphthalen1(2H)-one) (3) (Scheme 1).

Reaction of compound $\mathbf{3}$ with nitrilimines (generated in situ via triethylamine dehydro-halogenation of the corresponding hydrazonoyl halides, 4) in 1:2 molar ratio in dry benzene under reflux gave dicycloadduct compound $\mathbf{5}$, which were identified by different spectroscopic techniques as well as elemental analyses data. The IR spectra of the isolated products 5 reveal the carbonyl absorption bands in the region $v 1660-1684 \mathrm{~cm}^{-1}$. The appearance of a singlet signal in ${ }^{1} \mathrm{H}$ NMR spectra at $\delta 5.04$ $5.52 \mathrm{ppm}$ assignable to the pyrazole $\mathrm{H}-4$, ruled out the formation of the isomeric dicycloadduct compound 6 [40-44] (Scheme 1).

On the other hand, reaction of 2,2'-(1,4-phenylene bis(methanylylidene)) bis(1H-indene-1,3(2H)-dione) (8) with hydrazonoyl halides 4a-e in the 1: 1 molar ratio in refluxing benzene in the presence of triethylamine as basic catalyst for $10 \mathrm{hr}$, afforded only one isolable regioisomer, the structure of which was established to be the monocycloadduct 9 based on spectral and elemental analyses data. For example, the ${ }^{1} \mathrm{H}$ NMR spectra of compounds 9 revealed the presence of two singlet signals at $\delta$ 5.08-5.41 ppm and 9.90-9.93 ppm assigned for the pyrazole $\mathrm{H}-4$ and methylene $\mathrm{CH}$ protons, respectively. Repetition of the reaction of 2,2'-(1,4-phenylene bis(methan ylylidene) $)$ bis( $1 H$-indene-1,3(2H)-dione) (8) with hydrazonoyl halides 4a-e in 1:2 molar ratio in refluxing benzene for $50 \mathrm{hr}$ afforded two dicycloadducts compounds $\mathbf{1 0 a}$,d and monocycloadducts compounds $\mathbf{9 b}, \mathbf{c}$ and $\mathbf{e}$.

The structure of dicycloadduct compounds 10a,d was established on the bases of spectral data and elemental analyses. The ${ }^{1} \mathrm{H}$ NMR spectra of compound 10a revealed a singlet signal at $\delta 5.12 \mathrm{ppm}$ assigned for the pyrazole $\mathrm{H}-4$ and the absence of the singlet signal of the methylene $\mathrm{CH}$ proton. Many attempts have been carried out for either identification or isolation of the other dicycloadduct compounds $\mathbf{1 0 b}, \mathbf{c}, \mathbf{e}$ isomers but they were unsuccessful. Many other attempts have been made for identification of cycloadducts compounds $\mathbf{5}, \mathbf{9}$, 10 and their optically stereochemical configurations, using single crystal X-ray diffraction technique, but gave no satisfactory results.

\subsection{Theoretical calculations of the ground state energy}

The molecular geometry for all compounds under study were obtained by full geometry optimization using hybrid density functional theory B3LYP method, where (B3) [45-47] stands for Becke's three parameter exact exchange-functional combined with gradient-corrected correlation functional of Lee, Yang and Parr (LYP) [48] by implementing 6-311G(d,p) as a basis set $[49,50]$. All the calculations were done using the Gaussian 09 software package [51]. The optimized structures were visualized using GaussView version 5.0.9 [52].

The possible pathways products are all isomers, so the total energy can be used to investigate which pathway is more favored from the thermodynamic point of view. The energy of the reactants and products for the most stable conformer are summarized in Table 1 . The energy gap $\Delta E$ is the energy difference between the energy of LUMO and energy of HOMO. The optimized geometry of compounds $3, \mathbf{4 a}, \mathbf{5 a}$ and $\mathbf{6 a}$ are provided in the supporting information. The energies of the products (compound $\mathbf{6 a}$ or $\mathbf{5 a}$ ) are less than energies of reactants (compound $\mathbf{3}$ and $\mathbf{4 a}$ ) with almost the same value of 80.7 Hartree this difference is the energy of the reaction. 
Table 2. Antimicrobial activity expressed as inhibition diameter zones in millimeter ( $\mathrm{mm}$ ) of compounds 3, 5, 8, 9 and 10 against the pathological strains based on well diffusion as assay*.

\begin{tabular}{|c|c|c|c|c|c|c|c|c|}
\hline \multirow[t]{2}{*}{ Compound } & \multicolumn{4}{|l|}{ Fungi } & \multicolumn{2}{|c|}{ Gram positive bacteria } & \multicolumn{2}{|c|}{ Gram negative bacteria } \\
\hline & $\begin{array}{l}\text { Aspergillus } \\
\text { fumigatus }\end{array}$ & $\begin{array}{l}\text { Syncephalastrum } \\
\text { racemosum }\end{array}$ & $\begin{array}{l}\text { Geotricum } \\
\text { candidum }\end{array}$ & $\begin{array}{l}\text { Candida } \\
\text { albicans }\end{array}$ & $\begin{array}{l}\text { Staphylococcus } \\
\text { aureus }\end{array}$ & $\begin{array}{l}\text { Bacillus } \\
\text { subtilis }\end{array}$ & $\begin{array}{l}\text { Pseudomonas } \\
\text { aeruginosa }\end{array}$ & $\begin{array}{l}\text { Escherichia } \\
\text { coli }\end{array}$ \\
\hline 3 & $15.3 \pm 0.63$ & $16.7 \pm 0.25$ & $18.8 \pm 0.44$ & N.A. & $18.3 \pm 0.19$ & $19.3 \pm 0.25$ & N.A. & $15.2 \pm 0.58$ \\
\hline $5 a$ & $14.3 \pm 0.58$ & $15.2 \pm 0.44$ & $17.3 \pm 0.58$ & N.A. & $18.3 \pm 0.44$ & $19.6 \pm 0.58$ & N.A. & $13.4 \pm 0.44$ \\
\hline $5 b$ & $20.2 \pm 0.37$ & $21.7 \pm 0.44$ & $22.6 \pm 0.37$ & N.A. & $20.6 \pm 0.58$ & $22.8 \pm 0.25$ & N.A. & $18.3 \pm 0.63$ \\
\hline $5 f$ & $16.3 \pm 0.37$ & $17.2 \pm 0.58$ & $17.9 \pm 0.44$ & N.A. & $18.9 \pm 0.58$ & $20.2 \pm 0.63$ & N.A. & $15.0 \pm 0.44$ \\
\hline 8 & $10.3 \pm 0.58$ & $12.6 \pm 0.34$ & $13.7 \pm 0.44$ & NA & $11.6 \pm 0.58$ & $13.0 \pm 0.67$ & N.A. & $9.8 \pm 0.44$ \\
\hline $9 a$ & $12.3 \pm 0.44$ & $15.9 \pm 0.58$ & $16.3 \pm 0.34$ & N.A. & $17.1 \pm 0.58$ & $18.8 \pm 0.44$ & N.A. & $12.6 \pm 0.58$ \\
\hline $10 \mathrm{a}$ & $12.3 \pm 0.58$ & $15.2 \pm 0.63$ & $13.3 \pm 0.44$ & NA & $14.2 \pm 0.25$ & $15.3 \pm 0.58$ & N.A. & $11.1 \pm 0.44$ \\
\hline$\overline{\text { Amphotericin B }}$ & $23.7 \pm 0.1$ & $19.7 \pm 0.2$ & $28.7 \pm 0.2$ & $25.4 \pm 0.1$ & N.A. & N.A. & N.A. & N.A. \\
\hline Ampicillin & - & - & - & - & $23.8 \pm 0.2$ & $32.4 \pm 0.3$ & - & - \\
\hline Gentamicin & - & - & - & - & - & - & $17.3 \pm 0.1$ & $19.9 \pm 0.3$ \\
\hline
\end{tabular}

* The experiment was carried out in triplicate and average zone of inhibition was calculated; (N.A.= no activity).

HOMO

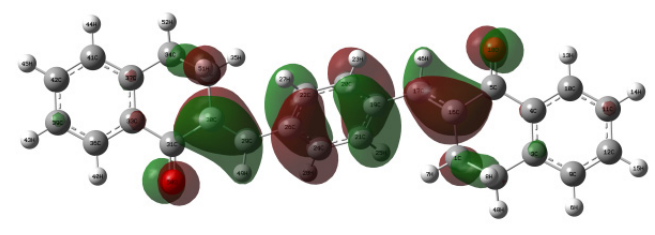

Compound 3

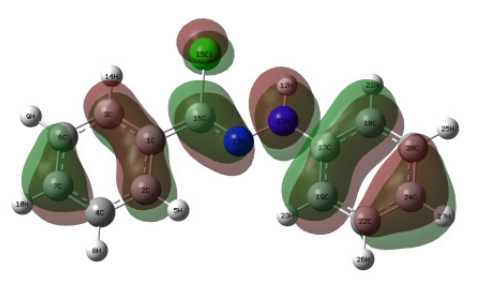

Compound 4a
LUMO

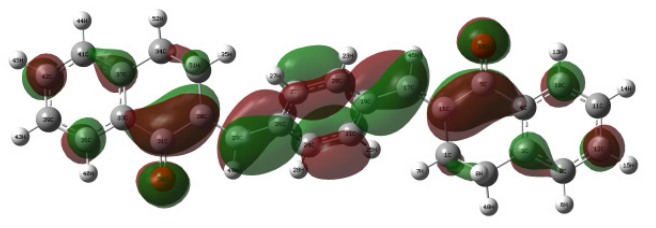

Compound 3

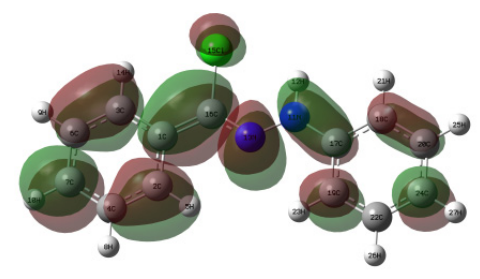

Compound 4a

Figure 1. The molecular orbital plot for the HOMO and LUMO of compounds $\mathbf{3}$ and $\mathbf{4 a}$.

The stability of the products over the reactants indicates an exothermic reaction. The energy of compound $\mathbf{6 a}$ is slightly more stable than compound $\mathbf{5 a}$ by $0.71 \mathrm{kcal} / \mathrm{mol}$. The energy difference between compound $\mathbf{5 a}$ and compound $\mathbf{6 a}$ is not vastly decisive compared to the energy of the reaction (i.e. $0.0014 \%$ of the energy of the reaction). This can be clearly seen by applying the well known Boltzman population analysis at $298.15 \mathrm{~K}$ for an energy difference of $0.71 \mathrm{kcal} / \mathrm{mol}$ between to singly degenerate states which results in $23.2 \%$ of the molecules will populate the upper state. The small energetic difference cannot be used to explain the stereo-selectivity of this reaction.

The better explanation for the proposed mechanism can be clearly done using a deeper look to the molecular orbital plots. Figure 1 shows the HOMO and LUMO of compounds $\mathbf{5 a}$ and $\mathbf{6 a}$. The reaction was expected to proceed via interaction of HOMO of one reactant with LUMO of another. This treatment can give a clearer picture to which pathway the reaction will proceed by comparing the sign of the molecular orbital lobes at the site of the reaction. A similar sign indicates a possibility of bonding molecular orbital while a different signs indicates an impossible reaction or anti-bonding molecular orbital overlap. In a direct statement, the similar sign of the lobes indicates the direction of the reaction. Figure 2 shows the HOMO of compound 3 (in two different orientations to form compound $\mathbf{5 a}$ or $\mathbf{6 a}$ ) and LUMO of compound $\mathbf{4 a}$. The possible sites of interaction in Figure 2 of compound $\mathbf{3}$ with compound $\mathbf{4 a}$ are labeled with dotted arrows. The molecular orbital signs in Figure 2 show that there is only one possibility to form compound 5a (green lobes with green lobes) as it leads to constructive bonding overlap. The other pathway is not possible since color of lobes are mismatched (green lobes with red lobes) will result in destructive antibonding overlap. The molecular orbital lobes colors indicate that, there is only one possible mechanism for the interaction of the reactant to form only compound $\mathbf{5 a}$. The same theoretical procedure shows that compound $\mathbf{5}$ is always more favored over compound $\mathbf{6}$ irrespective to the substituent effect.

\subsection{Antimicrobial activity}

In-vitro antimicrobial screening of compounds $\mathbf{3}, \mathbf{5 a}, \mathbf{b}, \mathbf{f}, \mathbf{8}$, 9a and 10a prepared in this study was carried out using cultures of four fungal strains, including Aspergillus fumigatus (RCMB 02568), Syncephalastrum racemosum (RCMB 05922), Geotricum candidum (RCMB 05097) and Candida albicans (RCMB 05031), as well as four bacteria species, namely, Gram positive bacteria, Staphylococcus aureus (RCMB 010010) and Bacillus subtilis (RCMB 010067), Gram negative bacteria, Pseudomonas aeruginosa (RCMB 010043) and Escherichia coli (RCMB 010052). Amphotericin B as an antifungal agent, Ampicillin as an antibacterial agent for Gram positive bacteria and Gentamicin as an antibacterial agent for Gram negative bacteria was used as references to evaluate the potency of the tested compounds under the same conditions.

From the results depicted in Table 2, we found that compound $\mathbf{3}$ has moderate activity against all microorganisms used. But the pyrazoline ring found in compounds $\mathbf{5}$ dramatically increase the activity as in compound $\mathbf{5 b}$ which becomes more reactive than the reference drug for Syncephalastrum racemosum (RCMB 05922). 
Table 3. Minimum inhibitory concentration $(\mu \mathrm{g} / \mathrm{mL})$ against the pathological strains.

\begin{tabular}{|c|c|c|c|c|c|c|c|c|}
\hline \multirow[t]{2}{*}{ Compound } & \multicolumn{4}{|l|}{ Fungi } & \multicolumn{2}{|c|}{ Gram positive bacteria } & \multicolumn{2}{|c|}{ Gram negative bacteria } \\
\hline & $\begin{array}{l}\text { Aspergillus } \\
\text { fumigatus }\end{array}$ & $\begin{array}{l}\text { Syncephalastrum } \\
\text { racemosum }\end{array}$ & $\begin{array}{l}\text { Geotricum } \\
\text { candidum }\end{array}$ & $\begin{array}{l}\text { Candida } \\
\text { albicans }\end{array}$ & $\begin{array}{l}\text { Staphylococcus } \\
\text { aureus }\end{array}$ & $\begin{array}{l}\text { Bacillus } \\
\text { subtilis }\end{array}$ & $\begin{array}{l}\text { Pseudomonas } \\
\text { aeruginosa }\end{array}$ & $\begin{array}{l}\text { Escherichia } \\
\text { coli }\end{array}$ \\
\hline$\overline{3}$ & 125 & 62.5 & 1.81 & N.A. & 15.63 & 7.81 & NA & 125 \\
\hline $5 a$ & 125 & 125 & 31.25 & N.A. & 15.63 & 7.81 & NA & 500 \\
\hline $5 b$ & 3.9 & 1.95 & 0.098 & NA & 3.9 & 0.098 & NA & 15.63 \\
\hline $5 f$ & 62.5 & 31.25 & 15.63 & NA & 7.81 & 3.9 & NA & 125 \\
\hline Amphotericin B & 0.49 & 3.9 & 0.03 & 0.12 & - & - & - & - \\
\hline Ampicillin & - & - & - & NA & 0.49 & 0.007 & - & - \\
\hline Gentamicin & - & - & - & - & - & - & 31.25 & 7.81 \\
\hline
\end{tabular}
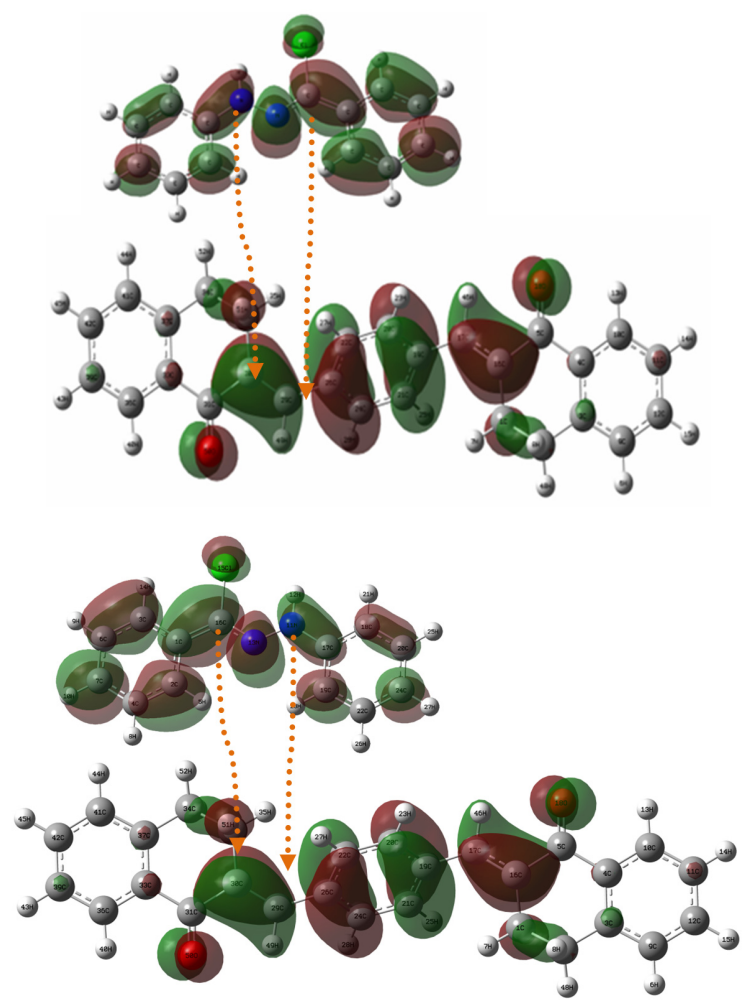

Figure 2. The molecular orbital plots for the HOMO of compound 3 and LUMO of compound $\mathbf{4 a}$ to form compound $\mathbf{5 a}$ in the upper and compound $\mathbf{6 a}$ in the lower parts.

On the other hand, the starting compound $\mathbf{8}$ is less reactive than 3, but, pyrazoline ring found in compounds 9a and 10a increases slightly the activity. The minimum inhibitory concertation $(\mu \mathrm{g} / \mathrm{mL})$ of compound $\mathbf{5 b}$ showed activity more than the reference drug Amphotericin $B$ for the fungi Syncephalastrum racemosum (Table 3 ). From the above results, we can conclude that the pyrazoline moiety increases the activity against the microbial organisms used.

\section{Conclusion}

New series of compounds 5, $\mathbf{9}$ and $\mathbf{1 0}$ were synthesized via 1,3-dipolar cycloaddition of $\left(2 E, 2^{\prime} E\right)-2,2^{\prime}-(1,4$-phenylenebis(methanylylidene))bis(3,4-dihydronaphthalen-1(2H)-one) 3 and 2,2'-(1,4-phenylenebis(methanylylidene) $)$ bis(1H-indene1,3(2H)-dione) 8 to a variety of nitrilimines intermediates. The mechanisms of the reactions studied are discussed and the structures of the products were confirmed by spectral and elemental analyses. The proposed procedure for studying the stereoselectivity of the reaction using the theoretical molecular orbital plot is highly recommended to prove the proposed mechanism theoretically. Also, molecular orbital plots for HOMO and LUMO verify our suggested mechanism and stereoselectivity of the reaction. The antimicrobial activity of the products was evaluated and promising results were obtained.

\section{References}

[1]. Berquist, P. R.; Wells, R. J. Chemical and Biological Perspectives, vol. 5, Academic Press, New York, 1993, pp. 1-50.

[2]. Encarnacion, R. D.; Sandoval, E.; Malmstrom, J.; Christophersen, C. J. Nat. Prod. 2000, 63, 874-875.

[3]. James, D. M.; Kunze, H. B.; Faulkner, D. J. J. Nat. Prod. 1991, 54, $1137-$ 1140.

[4]. Girgis, A. S.; Ibrahim, Y. A.; Mishriky, N.; Lisgarten, J. N.; Potterc; B. S.; Palmer, R. A. Tetrahedron 2001, 57, 2015-2019.

[5]. Fisera, L.; Sauter, F.; Frohlich, J.; Feng, Y.; Ertl, P.; Mereiter, K. Monatsh. Chem. 1994, 125, 553-563.

[6]. Fisera, L.; Sauter, F.; Frohlich, J.; Feng, Y.; Mereiter, K. Monatsh. Chem. 1994, 125, 909-919.

[7]. Strauss, A.; Otto, H. H. Helv. Chim. Acta, 1997, 80, 1823-1830.

[8]. Stverkova, S.; Zak, Z.J. Liebigs Ann. Chem. 1995, 477-480.

[9]. Riyadh, S. M.; Farghaly, T. A. Tetrahedron 2012, 68(44), 9056-9060.

[10]. Padwa, A. 1,3-Dipolar cycloaddition reactions, Vol. 1, Wiley: New York, 1984, pp. 291

[11]. Girgis, A. S.; Ibrahim, Y. A.; Mishriky, N.; Lisgarten, J. N.; Potter, B. S.; Palmer, R. A. Tetrahedron 2001, 57(10), 2015-2019.

[12]. Lee, H. H.; Cain, B. F.; Denny, W. A. J. Org. Chem. 1989, 54, 428-431.

[13]. Claramunt, R. M.; Elguero. J. Org. Prep. Proced. Int. 1991, 23, 273-320.

[14]. Havaldar, F. H.; Fernandes, P. S. J. Indian Chem. Soc. 1988, 65, 691-694.

[15]. Sachchar, S. P.; Singh, A. K. J. Indian Chem. Soc. 1985, 62, 142-146.

[16]. Sangwan, N. K.; Dhindsa, K. S.; Malik, O. P.; Malik, M. S. Chim. Acta Turc. 1983, 11, 65-72.

[17]. Berenson, H. (American Cyanamid Co.), U. S. 3, 947, 583 (Cl. 242-273; A01N), 30 Mar. 1976; Chem. Abstr. 85, 1211 (1976).

[18]. Satti, N. K.; Suri, K. A.; Suri, O. P. Indian Drugs 1987, 24, 492-493.

[19]. Fauran, C.; Turin, M. G.; Pourrias, B. (Delalande, S. A.), Fr. Demande 2, 259, 590 (Cl. A61 K, C07D), 29 Aug. 1975; Chem. Abstr. 84, 59477 (1976).

[20]. Sawhney, S. N.; Dhindsa, G. S.; Vir, D. J. Indian Chem. Soc. 1988, 65 643-645.

[21]. Reis, H.; Vilhuber, H. G.; Schulz, L.; Leuke, D. (BASF A. -G.), Ger. Offen. 2, 525, 024 (Cl. C07D403/12), 30 Dec. 1976; Chem. Abstr. 86, 140042 (1977).

[22]. Bruno, O.; Ranise, A.; Bondavalli, F.; Schenone, P. Farmaco 1992, 47, 1235-1248.

[23]. Vinge, E.; Bjoerkman, S. Acta Pharmacol. Toxicol. 1986, 59, 165-174.

[24]. Bailey, D. M.; Hansen, P. E.; Hlavac, A. G.; Baizman, E. R.; Pearl, J.; De Felice, A. F.; Feigenson, M. E. J. Med. Chem. 1985, 28, 256-260

[25]. Farghaly, T. A.; Abdallah, M. A.; Abdel Aziz, M. R. Molecules 2012, 17, 14625-14636.

[26]. Farghaly, T. A.; Gomha, S. M.; Abbas, E. M. H.; Abdalla, M. M. Arch. Pharm. Chem. Life Sci. 2012, 345, 117-122.

[27]. Farghaly, T. A.; Hassaneen, H. M. E. Arch. Pharm. Res. 2013, 36, 564572 .

[28]. Farghaly, T. A.; Mahmoud, H. K. Arch. Pharm. Chem. Life Sci. 2013, 346, 392-402.

[29]. Farghaly, T. A.; Riyadh, S. M.; Abdallah, M. A.; Ramadan, M. A. Acta. Chim. Slov. 2011, 58, 87-94.

[30]. Ariens, E. J.; Drug Design, Vol. 1., Ariens, E. J.; Editor. P. 1. Academic Press, New York, 1971.

[31]. Saint-Ruf, G.; Buu-Hoi, N. P.; Jacouignon, P. J. Chem. Soc. 1960, 35(8), 2690-2694.

[32]. Wolkoff, P. Can. J. Chem. 1975, 53(9), 1333-1335.

[33]. Hassaneen, H. M.; Hilal, R. H.; Elwan, N. M.; Harhash, A.; Shawali, A. S. J. Heterocyclic Chem. 1984, 21, 1013-1016.

[34]. Hassaneen, H. M.; Mousa, H. A. H.; Abed, N. M.; Shawali, A. S. Heterocycles 1988, 27, 695-706.

[35]. Holder, I. A.; Boyce, S. T. Burns 1994, 20, 426-429.

[36]. Agwa, H.; Aly, M. M.; Bonaly, R. J. Union Arab. Biol. 2000, 7, 62-82.

[37]. Doughari, J. H. Trop. J. Pharm. Res. 2006, 5, 597-603. 
[38]. Midgley, G.; Clayton, Y.; Hay, J. Diagnosis in color medical mycology, international, UK. Mosby-Year Book, 1997, pp. 14-17.

[39]. Shiriling, E. M.; Gottlieb, D. Int. J. Syst. Bact. 1966, 16, 313-340.

[40]. Girgis, A. S.; Osman, F. H.; El-Samahy, F. A.; Ahmed-Farag. I. S.; Chem Pap. 2006, 60, 237-242.

[41]. Boudriga, S.; Askri, M.; Gharbi, R.; Rammah, M.; Ciamala, K. J. Chem. Res. (S) 2003, 2003, 204-207.

[42]. Girgis, A. S.; Ismail, N. S. M.; Farag, H.; George, R. F.; Eur. J. Med. Chem. 2010, 45, 4229-4238.

[43]. Girgis, A. S.; Farag, H.; Ismail, N. S. M.; George, R. F. Eur. J. Med. Chem 2011, 46, 4964-4969.

[44]. Girgis, A. S.; Ibrahim, Y. A.; Farag, A. I. S.; Mishriky, N. J. Chem. Res. (S), 2000, 2000, 508-509.

[45]. Becke, A. D. Phys. Rev. A 1988, 38, 3098-3100.

46]. Becke, A. D. J. Chem. Phys. 1993, 98, 5648-5652.

[47]. Johnson, B. G.; Frisch, M. J. Chem. Phys. Lett. 1993, 216, 133-140.

[48]. Lee, C.; Yang, W.; Parr, R. G. Phys. Rev. B 1988, 37, 785-789.

[49]. McLean, A. D.; Chandler. G. S.; Chandler, G. S. J. Chem. Phys. 1980, 72, 5639-5648.

[50]. Raghavachari, K.; Binkley, J. S.; Seeger, R.; Pople.; J. A. J. Chem. Phys. 1980, 72, 650-654.

[51]. Frisch, M. J.; Trucks, G. W.; Schlegel, H. B.; Scuseria, G. E.; Robb, M. A.; Cheeseman, J. R.; Scalmani, G.; Barone, V.; Mennucci, B.; Petersson, G. A.; Nakatsuji, H.; Caricato, M.; Li, X.; Hratchian, H. P.; Izmaylov, A. F.; Bloino, J.; Zheng, G.; Sonnenberg, J. L.; Hada, M.; Ehara, M.; Toyota, K.; Fukuda, R.; Hasegawa, J.; Ishida, M.; Nakajima, T.; Honda, Y.; Kitao, O.; Nakai, H.; Vreven, T.; Montgomery, J. A.; Peralta, Jr.; J. E.; Ogliaro, F.; Bearpark, M.; Heyd, J. J.; Brothers, E.; Kudin, K. N.; Staroverov, V. N.; Keith, T.; Kobayashi, R.; Normand, J.; Raghavachari, K.; Rendell, A.; Burant, J. C.; Iyengar, S. S.; Tomasi, J. M.; Cossi, N.; Rega, J. M.; Millam, M.; Klene, J. E.; Knox, J. B.; Cross, V.; Bakken, C.; Adamo, J.; Jaramillo, R.; Gomperts, R. E.; Stratmann, 0.; Yazyev, A. J.; Austin, R.; Cammi, C.; Pomelli, J. W.; Ochterski, R. L.; Martin, K.; Morokuma, V. G.; Zakrzewski, G. A.; Voth, P.; Salvador, J. J.; Dannenberg, S.; Dapprich, A. D.; Daniels, O.; Farkas, J. B.; Foresman, J. V.; Ortiz, J.; Cioslowski, D. J.; Fox, Gaussian, Inc.; Wallingford CT, 2010.

[52]. GaussView, Version 5, R. Dennington, T. Keith, J. Millam, Semichem Inc.; Shawnee Mission KS, 2009. 